\title{
Fiziksel Kimliği Koruma ve İmaj Geliştirme Üzerine Bir Yerleşim Deneyimi: Osmaneli (Bilecik) Örneği
}

\section{A Settlement Experience on Protection of Physical Identity and Image Enhancement: The Example of Osmaneli (Bilecik)}

\author{
Özlem Candan Hergül ${ }^{1 *}$, İrfan Dönmez ${ }^{2}$, Hilal Kahveci ${ }^{3}$, Mine Poyraz ${ }^{4}$ \\ Geliş / Received: 22/04/2021 \\ Revize / Revised: 08/06/2021 \\ Kabul / Accepted: 08/06/2021
}

ÖZ

Yoğun kentleşme hareketleri, aşırı tüketim, enerji kaynaklarının bilinçsiz kullanımı, çeşitli sebeplerle insanların büyük kentlere göç etmesi ve hızlı nüfus artı̧̧ günümüz kentlerinin ortak sorunlarıdır. Kentlerle ilgili sorunların farkına varan bazı yerel yönetimler 1999 yılında İtalya'da Yavaş Kent Hareketi (Cittaslow Movement) adında bir kentsel hareket başlatmışlardır. Yavaş Kent Hareketi'nin temel hedefi, mekanların gelişimini iyi yemek, sağlıklı çevreler, sürdürülebilir ekonomi ve toplumsal yaşamın geleneksel ritüelleri esas alınarak beslemektir. Yavaş Kent olmaya aday kentler; yerel sanat ve zanaatleri teşvik etmenin yanı sıra ürünleri bölgeyi tanımlı kılan, bölgeye kimlik ve imaj kazandıran modern endüstrinin desteklenmesini de sağlamak üzere faaliyet gösterirler. Ayrıca, yapılı çevrenin karakterinin korunması, ağaç dikimi; yeşil alanların, bisiklet yollarının ve yayalaştııılmış bölgelerin arttırılması, meydanların reklam panoları ve neonlardan arındırılmış olması, araba alarmlarının yasaklanması, gürültü kirliliğinin, 1şık kirliliğinin ve hava kirliliğinin azaltılması, alternatif enerji kullanımının desteklenmesi, toplu taşımanın ve yeni düzenlemeler içinde ekoloji dostu mimarinin geliştirilmesi de Yavaş Kent'lerin zorunlu uygulamalarından bazılarıdır.

Bilecik ili Ankara, İstanbul, Eskişehir, Bursa gibi büyük kentlere yakın olmasıyla coğrafi olarak, çeşitli uygarlıklara ev sahipliği yapması ve Osmanlı Devleti'nin kuruluşunda merkez görevi görmesi ve Kurtuluş Savaşı'nda verdiği mücadelelerle tarihi olarak önemli bir konumdadır. Çalışma ile Osmaneli kentinin Yavaş Kent Hareketi'ne katılmaya uygunluk durumunun incelenmesi, Yavaş Kent Hareketi'ne katılmanın Osmaneli kent imajını geliştirmeye yönelik yapacağı olumlu fiziksel etkilerin saptanması ve tasarıma yönelik önerilerin geliştirilmesi hedeflenmiş̧ir.

Anahtar Kelimeler- Kent Kimliğ̈i, Kent İmajı, Yavaş Kent Hareketi, Osmaneli

\footnotetext{
ABSTRACT

Intense movement in the urbanization, devilish consumption, unconscious usage of energy sources, migration of people to big cities for any reason and rapid growth in the population can be counted as the common problems of the recent cities. Some local administrations in Italy, which became aware of problems about cities, initiated a

1*Sorumlu yazar iletișim: ozlem.hergul@bilecik.edu.tr (https://orcid.org/0000-0001-7140-0149)

İç Mimarlık ve Çevre Tasarımı, Bilecik Şeyh Edebali Üniversitesi, Güzel Sanatlar ve Tasarım Fakültesi, Gülümbe, Bilecik 2İletişim: irfan.donmez@bilecik.edu.tr (https://orcid.org/0000-0002-1529-0771)

Resim Bölümü, Bilecik Şeyh Edebali Üniversitesi, Güzel Sanatlar ve Tasarım Fakültesi, Gülümbe, Bilecik

3İletişim: hilal.kahveci@bilecik.edu.tr (https://orcid.org/0000-0002-4516-7491)

İç Mimarlık ve Çevre Tasarımı, Bilecik Şeyh Edebali Üniversitesi, Güzel Sanatlar ve Tasarım Fakültesi, Gülümbe, Bilecik 4İletişim: mine.poyraz@bilecik.edu.tr (https://orcid.org/0000-0002-4693-6985)

Seramik ve Cam Tasarımı Bölümü, Bilecik Şeyh Edebali Üniversitesi, Güzel Sanatlar ve Tasarım Fakültesi, Gülümbe, Bilecik
} 
movement called Slow City Movement (Cittaslow Movement) in 1999. Primary objective of the Slow City Movement is to feed the development of the spaces being predicated on the better food, sustainable economy, healthy environments, and traditional rituals of the social life. Slow city candidate cities show activity to support modern industry which their products define and give identity to the region as well as to encourage local art and craft. To protect the characteristics of built environment, planting trees, increasing the amount of green spaces, bicycle paths and pedestrianized areas, to decontaminate squares from billboards and neon, to forbid car alarms, to reduce noise pollution, light pollution and air pollution, to support alternative energy use, to develop public transport and eco-friendly architecture in new regulations are also some of mandatory implementations of Slow Cities.

Bilecik has a significant location; geographically, as it is close to major cities, such as Ankara, Istanbul, Eskişehir, Bursa and historically; hosting of various civilizations and serving as a center for the establishment of the Ottoman Empire and its struggle in the War of Independence. The aim of the study is to examine the suitability of Osmaneli city to participate the Slow City Movement as a member and to determine the positive physical effects of participating to the Slow City Movement towards improving the city image and also to develop design suggestions for the district.

\section{Keywords- Urban identity, urban image, Slow City Movement, Osmaneli}

\section{GíRiş}

Kaliteli yaşama isteği, geçim sıkıntıları, görsel medyanın yarattığı kent hayatı rüyası; insanları kırsal alanlardan, kasaba ve köylerinden büyük şehirlere göç etmeye teşvik etmektedir. Bu durum da kentlerin her geçen gün daha fazla yapılaşmasına, alt yapı ve güvenlik sorunları oluşmasına zemin hazırlamaktadır. Bireylerin, aileleriyle birlikte büyük şehirlerde var olma isteğinin ana nedeni; yaşadıkları kırsal alanlarda istihdam olanaklarının kısıtlı olmasıdır. Özellikle genç nüfus için iş bulmak, hayat kurmak kırsal bölgelerde zorlaşmıştır.

Büyük şehirlerin kalabalıklaşması, kentsel nice sorunu beraberinde getirirken, kırsal bölgelerde de genç nüfusun azalması, eski mesleklerin unutulması ve tarımsal faaliyetlerin azalmasına sebep olmaktadır. Bu nedenle küçük kentlerde ya da kasabalarda yapılacak girişimlerin önünün açılması o bölgedeki yaşam kalitesini ve olumlu değerleri artıracaktır.

Hızlı ve tüketime dayalı yaşam biçimleri; bireyleri ve toplumları benzer yaşam kalıplarının ve tüketim alışkanlıklarının şekillendiği, birbirinin aynısı konutlarda, yeşil alanlardan ve doğal yaşamdan uzak bir biçimde yaşamaya hapsetmektedir. Sanayi Devrimiyle başlayan bu süreç, günümüzde kapitalizm gerçeğiyle en vahşi halini almıştır. Yavaş Kent Hareketi; küçük kentler için kırsal kalkınma sağlaması açısından değerli bir yaklaşımı barındırmaktadır. Kimliğini ve yerel değerlerini koruyarak sürdürmek ve gelişmek isteyen küçük kentlerde bu hareket doğrultusunda yapılacak çalışmalar; kente yönelik nitelikli kazanımların önünü açacaktır.

Bu noktada kendi ekonomik döngüsünü sağlayan, kimlikli bir yapıya sahip ve yerel ürünleri olan yerleşimler önem kazanmaktadır. Osmaneli; Bilecik’e bağlı küçük bir yerleşim olarak; tarihi evleri, tarımsal faaliyetleri ve nitelikli kentsel dokusuyla Yavaş Kent Hareketi'ne katılma yönünde adımlar atabilecek bir yerleşimdir.Bu bağlamda araştırma kapsamında; Osmaneli’nin tarihi, kültürel ve fiziksel dokusu detaylı olarak incelenerek, Osmaneli kentinde yaşayan insanlara uygulanan anketlerle Osmaneli halkının Yavaş Kent Hareketi'ne yaklaşımı konusunda bilgi edinilmiştir. Ayrıca anketler doğrultusunda kentin imaj ve kimlik değeri taşıyan ögeleri insan algısı üzerinden tespit edilmiştir. Ayrıca kentsel kimlik değeri taşıdığı saptanan öğeler fiziksel gelişim bağlamında görselleştirilerek tasarım önerileri geliştirilmiştir.

\section{A. Kent Kimliği}

Küresel dünya, kentleşme hızı, sanayileşme, teknolojik gelişmeler, savaşlar ve göç hareketlerinin yarattığı etkileşimler kentlerde büyük değişimlere yol açmıştır. Bu durumun neticesinde kentler; tarihi alanları zarar gören, geçmişinden kopuk, kentsel unsurların bütünsel bir tasarım anlayışı içermediği özgün kimliği olmayan mekanlara dönüşmektedir [1]. Kent kimliği karmaşık ve çok referanslı, maddi ve manevi olgular arasındaki bağları kapsayan, yerel, kentsel, bölgesel, ulusal gibi farklı ölçekleri bulunan, farklı perspektiflerden görülebilen, bireysel, kollektif, dışsal, zaman içinde gelişen, değişen ve birçok etmenden etkilenen bir olgudur [2]. Kent kimliği tüm yerel halkın 
geleneklerini, kültürünü, arzularının gruplanmış halini ifade eder. Onların ihtiyaçlarını, başarılarını, başarısızlıklarını ve geleceklerini yansıtır. Bazı zamanlarda, kent duyusal yerine teknik olarak anlaşılır ve yorumlanır, yine de hisler ve duygularla örüldüğünden duyusaldır. Duyusal gereksinimler, diğer gereksinimlerle uyumlu ya da çatışmacı olabilir fakat kentsel mekanların tasarım ya da değerlendirilmesinde onlardan ayrı düşünülemez [3].

Kent kimliği kısaca, bir kenti diğer kentlerden ayıran niteliklerin ve kente özgü ögelerin toplamı olarak adlandırılabilir. Bu farklılıklar, doğal çevre koşullarından ve tarihsel gelişim süreci içinde kazanılmış olan sosyoekonomik ve kültürel çevre koşullarından kaynaklanmaktadır. Kent kimliği, fiziksel mekan ve içinde yer alan yaşam biçimi ile bir bütün oluşturmaktadır [4]. Fiziksel gelişim, kentlerde somut, görsel ve kültürel bir varlık gösterir. Kentlerin fiziksel gelişimi; anlamları, öyküleri içerir ve şekillendirir. Alanların kimlik ya da kimliklerini fiziksel varlık ve öykülerin bu kombinasyonu yaratır [5]. Bir kenti diğer kentlerden ayıran, kendi özgü niteliklerini oluşturan her şey onun kimliğidir. Kimlik, farklı alanlarda ve sosyal durumlarda zaman ve sürekliliğin şekillendirdiği öznel bir duygudur [6].

\section{B. Kent Imajı}

Bir kentin imajı; kente dair, tüm fikir ve deneyimlerin bütününü kapsar ve kişiden kişiye algısal olarak değişim gösterir [7]. Kentlerin, belli bir amaca yönelik form ve karaktere sahip olması; sahip olduğu kimliğe bağlı estetik değerleri taşıması ve dolayısıyla bir kentsel imaj oluşturması ve duygusal belleği harekete geçirici bir nitelik taşımasını beraberinde getirmektedir [8]. Lynch (2010); kentin çevresel imajını üç bileşene ayırmaktadır: kimlik, yapı ve anlam. İmaj; bir nesnenin tanımlanmasını, dolayısıyla başka varlıklardan ayrıştırılmasını ve bir varlık olarak kabul edilmesini sağlar ve kimliğini ortaya koyar. Nesnenin imajı, yapının gözlemciyle mekansal ve dokusal ilişkisini kurar. Ayrıca, imaj; gözlemci için uygulama açısından ya da duygusal olarak bir anlam içermelidir [9].

Kısaca kent imajı kavramı; bir kentte yaşayan ya da kenti ziyaret eden bireylerin o kente dair zihinlerinde canlanan imgeleri içermektedir. Bu durumu belirleyen etkenler, kente ilişkin; fiziksel öğeler, yazılı, görsel ve sosyal medya kanalıyla edindikleri bilgiler, resimler, anılar ya da kentin geçirdiği dönüşümlere dair veriler bütünüyle şekillenmektedir.

\section{Yavaş Kent Hareketi}

Yirminci yüzyıl kentleri gürültü, kirlilik, plansız yapılaşma, yoksulluk ve suç gibi çok sayıda sorunla karşı karşıya kalmaktadır. Bu sorunlar birçok kentte yerel değerler, peyzaj, tarih, kültür ve doğal ekosistemlerin aşırı tüketimi gibi yaşanabilirlik değişkenlerinin sorgulanmasına yol açmış ve yerellik; sakinleri ve ziyaretçileri tarafından değersiz hale getirilmiştir [10]. Bu anlamda, kent alanları da özgünlükten uzak yerler haline dönüşmüş, ve de ironik bir biçimde bu süreç; profesyonel ellerce özgünleştirilmiş ve ticari olarak inşa edilmiş alanlarda ve mekanlarda geleneklerin önemsizleştiği, sterilize edildiği ve sembolik olarak basitleştirildiği ve mekansal bir kimlik yaratmak yerine insanları ticari bir kültür mirasına yakınlaştıran bir arayışı güçlendirmektedir [11].

Yavaş Hareketi, hızın egemenliği karşısında bireylerin, “anlamlı bir şeyler yapmak için” zaman ayırma çabası ya da arzusu olarak görülmelidir. Bu durum, günlük yaşam içerisinde yapılan her türlü etkinlikten daha fazla tat almak, yapılanı anlaşılır kılmak şeklinde özetlenebilir. Araba kullanmak yerine yürümek ya da bisiklete binmek için zaman yaratmak, hazır yemek almak yerine aile bireyleri ile birlikte geleneksel bir sofrada yemek yeme hazzını paylaşmak, yavaş yaşam uygulamaları arasındadır [12]. Yavaş Yemek ve genel olarak Yavaşlıkfelsefesinin yerleşim ölçeğindeki uygulamaları olarak sunulan Yavaş Kent, küçük ölçekli yerleşimlerin dokusunu, sakinlerinin yaşam biçimlerini ve bu ikisi arasındaki diyalektiğin yıllar içerisinde ortaya çıkarmış olduğu yerel kimliğigelecek kuşaklara aktarabilmeye yönelik politikalar üreten uluslararası bir birliktir [13]. Yavaş Kent Hareketi uluslararası bir hareket olmakla birlikte, yerele yönelik girişimler çerçevesinde bir model geliştirdiği için yerel yönetimler küreselleşmenin bazı formlarına karşı direnç kazanma uğraşı göstermektedirler [14]. Küreselleşmenin kentlere yönelik birbirine benzeştirici etkisi büyük kentler için öne çıkmakla birlikte küçük yerleşimler küreselleşme doğrultusunda kendi farklılıklarını ortaya koyarak ve firsata çevirerek ön plana çıkmaktadırlar.Yavaş kentler, özel ve kendine özgü niteliklerini saptamak vekorumak için kent yönetimleri içerisinde stratejik gelişime yönelik hedefler belirlemektedirler [15]. Yavaş Kent Hareketi, küreselleşme kaynaklı benzeşmeye karşı sosyal ve politik bir karşı duruş sergilemekle birlikte; geleneksel ve yerel yaşam biçimini koruyarak, küreselleşmenin olumsuzluklarına karşı alternatif bir sürdürülebilir kentsel gelişim modeli ortaya koymaktadır [16].

Cittaslow, özgünlüğünü koruma arayışında olan, kimlikli kentlerden oluşan üyeliğe dayalı bir birliktir. $\mathrm{Bu}$ uluslararası oluşuma üye kentler; ekolojik, tarihi, kültürel değerlerini, yöresel tatlarını, özgün mimari 
dokularını muhafaza etmek ve sürdürülebilirlik ilkeleri doğrultusunda geliştirmeyi hedeflemiş kentlerdir. Gelenekselliğin ön planda olduğu, monotonluktan uzak bir sakin yaşam modelini benimseyen bu kentleşme hareketi, küreselleşmenin yıkıcı etkileriyle yerel kimliğini koruyarak savaşmayı seçen bir politika izlemektedir.Yavaş Kent ölçütleri yedi ana başlık altında toplanmıştır. Bu başlıklar altındaki yaklaşık 70 madde Yavaş Kent olmak isteyen bir kent için gerçekleştirilmesi gereken değişkenlerdir.

Yavaş Kent olmak için başvuran yerleşimlerin hiçbirinden başvuru sırasında tüm gereklilikleri yerine getirmeleri beklenmemektedir. Ancak, bir kentin ölçütlerin en azından \%50 sini sağlayacak durumda olması ve henüz sahip olmadığı ölçütlere yönelik girişimlerde bulunacağı yükümlülüğünü üstlenmesi gerekmektedir [17].

Yavaş Kent olmak için gerekli uygulamaları içeren 7 ana başlık şunlardır [18]:

1. Enerji ve çevre politikaları

2. Altyap1 politikaları

3. Kentsel yaşam kalitesi politikaları

4. Tarım, turizm ve zanaat politikaları

5. Konukseverlik, farkındalık ve eğitim politikaları

6. Sosyal dayanışma konuları

7. İşbirlikleri

Dünya genelinde 30 ülkede toplam 276 yavaş kent bulunmaktadır. Türkiye'de ise 18 Cittaslow Birliği üyesi yerleşim bulunmakta ve ayrıca üyelik için hazırlanan ve adaylık başvurusunda bulunan potansiyel Yavaş kentlerle birlikte bu sayı 25 kentikapsamaktadır [19].

\section{II. ÇALIŞMA YÖNTEMI}

Araştırma alanının ana materyalini Bilecik İli’ne bağlı, il merkezinin 34 km kuzeyinde bulunan Osmaneli ilçesi oluşturmaktadır. Osmaneli'nde geçmişten bugüne gelen tarihi ve doğal peyzaj ögeleri, kentin imajını güçlendiren marka değeri taşıyan özellikleri çalışma içerisinde değerlendirilmektedir.

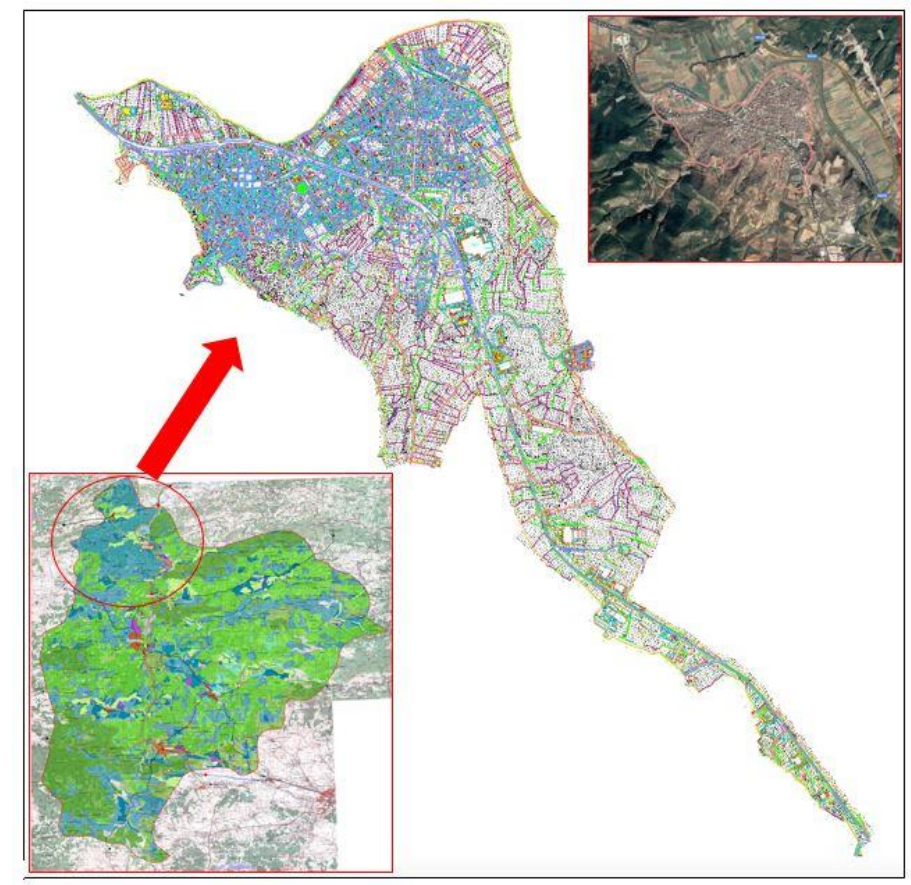

Şekil 1. Osmaneli’nin konumu 
Bilecik ili Osmaneli kentinin araştırma alanı olarak seçilmesinde aşağıdaki ögeler etkili olmuştur:

- Tarihi konakları, camileri, kilisesi gibi sit alanı olarak tescil edilmiş taşınmaz kültür varlıklarıyla; Osmaneli'nin kısmen korunmuş olan kimlikli bir dokusunun olması.

- Sakarya Nehri'nin kentten geçmesi ile önemli bir sulak alan ve rekreasyon potansiyeli oluşturması

- Doğa sporlarına olanak tanıyan bir coğrafyaya sahip olması

- Osmaneli'nde tarım faaliyetlerinin çeşitlilik sergilemesi ve elde edilen ürünlerin marka değer ve kırsal kalkınma yaratma konusunda yapacağı katkıların bulunması

Çalışma kapsamında, Osmaneli ilçesi tarihi evleri, nitelikli kentsel dokusu, yerel ürünlerinin varlığıyla kent imajı ve Yavaş Kent Hareketi’ne uygunluk kapasitesi sebebiyle çalışma alanı olarak seçilmiştir. Bu bağlamda Osmaneli ile ilgili literatürün detaylı analizi yapılmıştır. Araştırmada ikinci aşamayı arazi çalışmaları oluşturmaktadır. Bu doğrultuda Osmaneli'nde kente yönelik imaj ve marka değer taşıyan ögelerinin saptanması için anket çalışmaları yapılmıştır. Ankete ilişkin örneklem büyüklüğü belirlenmesi esasında çeşitli kaynaklar incelenmiş olup \%5 örnekleme hatası ile 244 kişi [20] olarak belirlenmiştir. Anketler doğrultusunda, alanda bulunan kimlik değeri yüksek, kent imajına katkı yapabilecek ögeler (yapılar, sokaklar, yeşil alanlar, meydanlar vb.) anketlerle saptanmış ve fotoğraflanmıştır. Daha sonra araştırma alanındaki eksikliklerin giderilmesi adına kurgu-tasar görüntüleri oluşturulmuş ve tasarım önerileri bağlamında değerlendirilmiştir.

Ayrıca bu aşamada kentin Yavaş Kent Hareketi maddelerine fiziksel açıdan uygunluğunun değerlendirilmesi için, peyzaj ögelerinin analizi de yapılmıştır. Bu bağlamda kentin imaj değerini artıracak olan peyzaj ögeleri saptanmış ve daha sonra Osmaneli'nin Yavaş Kent olma potansiyeli bu doğrultuda irdelenmiştir.

\section{ARASTTIRMA BULGULARI}

Osmaneli tarihi ve doğal güzellikleri olan, tarım ürünleriyle ön plana çıkan bir yerleşim olması sebebiyle kentte imaj değeri taşıyan birçok etmen bulunmaktadır. Bu bağlamda kent imajını ortaya koymak için katılımcılara bazı sorular sorulmuştur. Bu sorulara verilen cevaplar doğrultusunda yerel halkın algısı üzerinden yapılan değerlendirmeler şu şekildedir:

- Osmaneli'nin imajını şekillendiren en belirgin öge mimari dokuyu oluşturan tarihi konaklardır. Bir kısmı restore edilerek korunmuş, bir kısmı ise korunamamış olsa da yerleşimin özgün mimarisini belirleyen yapılardır. Bir diğer önemli öge ise Osmaneli'nin içinden geçen Sakarya Nehri ve nehrin kenarında konumlanan tesislerdir. Ayrıca sularının şifalı olduğu belirtilen İçmeler Tesisleri'de kimlik değeri açısından etkili olduğu düşünülen bölgelerdendir.

- Kent kimliğini şekillendiren ve imaj değeri taşıyan başka bir önemli belirleyici de pazarlama değeri taşıyan ürünlerin belirlenmesi ve marka değerlerinin ortaya konmasıdır. Bu konuda karpuz ve ayva öne çıkmaktadır. Ayrıca Osmaneli’nin özellikle ayvadan ve çeşitli meyvelerden yapılan lokumları da marka değeri taşımaktadır. Bununla birlikte Osmaneli'nde yerel üreticiler ve çoğunlukla kadın girişimciler tarafından üretilen 'Lefke Bezi' ismiyle adlandırılan tekstil ürününün de geçmişten bugüne kadar üretildiği ve imaj değeri taşıdığı sözlü görüşmelerde belirtilmiştir. Ayrıca Osmaneli Belediyesi Sürekli Eğitim Merkezi'nde lefke bezinden yapılan ürünlerin üretildiği ve bu konuda ustaların yetiştirildiği belirtilmiştir.

- Osmaneli’nin ön plana çıkan özellikleri aynı zamanda kimlik ve imajı yönlendirici ögelerdir. Ankette bu soruya verilen cevaplar önceki sorulara verilen cevapları destekleyici niteliktedir. Bu bağlamda Sakarya Nehri ve Tarihi konaklar en çok tercih edilen şıklar olmuştur. Daha sonra ise tarım ürünleri ve doğal güzellikler şıkları tercih edilmiştir.

Bilecik ili Osmaneli ilçesi; gerek tarihi dokusu ve mimari karakteristiği, gerek yöresel ürünleri ve kente kimlik kazandıran ögeleriyle önemli bir yerleşim alanıdır. Çalışma kapsamında Osmaneli'nin Yavaş Kent Hareketi'ne katılma uygunluğu üzerinden değerlendirmelerde bulunmak hedeflenmiş̧ir. Bu bölümde öncelikle Yavaş Kent Hareketi’nin kent imaj ve kimliğini güçlendirmeye yönelik doğrudan ya da dolaylı parametreleri aşağıda belirtilmiştir. Bu parametrelere ilişkin açıklamalar yapılmış, Osmaneli'nin mevcut durumu ve kentin imaj ve kimliğini güçlendirecek öneri ve değerlendirmeler Tablo 1'de detaylandırılmıştır. 
Tablo 1. Yavaş Kent Hareketi’nin imaj ve kimliğe ilişkin parametrelerinin, Osmaneli bazında değerlendirmelerini gösteren çizelge

\begin{tabular}{|c|c|c|c|}
\hline $\begin{array}{l}\text { Kent kimliği ve imajını } \\
\text { yönlendiren parametreler }\end{array}$ & Açıklamalar & Osmaneli'nin durumu & Öneriler \\
\hline $\begin{array}{l}\text { Görsel kirliliğin ve trafik } \\
\text { gürültüsünün azaltılması }\end{array}$ & $\begin{array}{l}\text { Yavaş Kentlerin genelinde } \\
\text { dükkan levhaları ve } \\
\text { tabelaların çeşitliliğinin } \\
\text { görsel kirlilik yaratması } \\
\text { sebebiyle tek tip, kent } \\
\text { estetiğine uygun } \\
\text { kullanımlar } \\
\text { desteklenmektedir. Trafik } \\
\text { gürültüsüne yönelik olarak } \\
\text { korna çalmak } \\
\text { kısıtlanmakta ve kent } \\
\text { merkezlerine araç girişi } \\
\text { denetlenmektedir. }\end{array}$ & $\begin{array}{l}\text { Osmaneli’de görsel kirliliğe } \\
\text { ilişkin sokak bazında örnekler } \\
\text { bulunmasına rağmen bazı } \\
\text { dükkanlarda birbirine benzer } \\
\text { doğal ahşap malzeme } \\
\text { kullanılan levhalar } \\
\text { bulunmaktadır. } \\
\text { Yerleşim temel olarak sakin bir } \\
\text { bölge olduğu için trafik } \\
\text { gürültüsüne yönelik rahatsız } \\
\text { edici bir durum yoktur. }\end{array}$ & $\begin{array}{l}\text { Bazı bölgelerde kullanılan } \\
\text { tabela ve levhalar kent geneline } \\
\text { yayılarak tüm dükkanların } \\
\text { tabelalarının belirli bir } \\
\text { standarda getirilmesi uygun } \\
\text { olacaktır. }\end{array}$ \\
\hline Kamusal ışık kirliliğinin azaltılması & $\begin{array}{l}\text { Kent genelinde farklı } \\
\text { yerlerden gelen } \\
\text { aydınlatmaların ve ticari } \\
\text { tabelalara yönelik } \\
\text { ışıklandırmaların yarattığı } \\
\text { karmaşayı ifade } \\
\text { etmektedir. }\end{array}$ & $\begin{array}{l}\text { Kentte bu bağlamda belirgin bir } \\
\text { problem saptanmamıştır. Bazı } \\
\text { bölgelerde bulunan 1şık } \\
\text { çeşitliliği kolaylıkla } \\
\text { çözümlenebilir. }\end{array}$ & $\begin{array}{l}\text { Kentteki tabela ve levhalara } \\
\text { getirilecek standartlar } \\
\text { 1ş1klandırma konusunda da } \\
\text { kolaylık sağlayacaktır. }\end{array}$ \\
\hline $\begin{array}{l}\text { Kamu binalarına bağlı verimli } \\
\text { bisiklet yolları }\end{array}$ & $\begin{array}{l}\text { Kentlerde bisiklet yolları } \\
\text { oluşturulması ve bunların } \\
\text { aktif olarak kullanılması } \\
\text { kentlerde motorlu araç } \\
\text { kullanımının azaltılmasını } \\
\text { sağlayacak ve ekolojik } \\
\text { sisteme olumlu etkileri } \\
\text { olacaktır. }\end{array}$ & $\begin{array}{l}\text { Kentte aktif kullanılan bir } \\
\text { bisiklet yolu bulunmamaktadır. }\end{array}$ & $\begin{array}{l}\text { Kent için bir bisiklet ulaşım } \\
\text { planı geliştirilebilir. } \\
\text { Osmaneli'nin topoğrafik yapısı } \\
\text { ve kullanımlar arası } \\
\text { mesafelerin yakın olması kent } \\
\text { içinde bisiklet dolaşımına } \\
\text { olanak tanımaktadır. }\end{array}$ \\
\hline $\begin{array}{l}\text { Metro ve otobüs durakları gibi } \\
\text { aktarma merkezlerinde bisiklet park } \\
\text { yerleri }\end{array}$ & $\begin{array}{l}\text { Kent içinde bisikletlerin } \\
\text { parkedilmesi için gerekli } \\
\text { alanları ifade etmektedir. }\end{array}$ & $\begin{array}{l}\text { Kentte bisiklet park yerleri } \\
\text { bulunmamaktadır. }\end{array}$ & $\begin{array}{l}\text { Bisiklet ulaşım planı } \\
\text { çerçevesinde bisiklet park } \\
\text { yerleri de belirtilmelidir. }\end{array}$ \\
\hline $\begin{array}{l}\text { Kente ait değerlerin iyileştirilmesi, } \\
\text { kent merkezlerinin ve kamu } \\
\text { binalarının değerlerinin arttırılması } \\
\text { için programlar }\end{array}$ & $\begin{array}{l}\text { Kentsel meydanların, } \\
\text { yapıların vb. kent estetiğini } \\
\text { ve imajını belirleyen } \\
\text { ögelerin geliştirilmesine } \\
\text { yönelik yapılacak stratejik } \\
\text { çalışma ve uygulamaları } \\
\text { ifade etmektedir. }\end{array}$ & $\begin{array}{l}\text { Osmaneli’de kent dokusunun } \\
\text { temel olarak korunduğunu } \\
\text { söylemek mümkündür. Ayrıca } \\
\text { kentteki tescilli yapıların bir } \\
\text { kısmı farklı zamanlarda restore } \\
\text { edilmiştir. } \\
\text { Kentte estetiği bozan özgün } \\
\text { kimliğe uymayan kent ögeleri } \\
\text { de bulunmaktadır. }\end{array}$ & $\begin{array}{l}\text { Kent estetiğine yönelik bazı } \\
\text { tasarım önerileri Şekil } 5.17 \text { ve } \\
\text { Şekil 5.18'de verilmiştir. }\end{array}$ \\
\hline $\begin{array}{l}\text { Verimli bitkiler ve meyve ağaçları } \\
\text { kullanılarak sosyal yeşil alanların } \\
\text { iyileştirilmesi ve/veya oluşturulması }\end{array}$ & $\begin{array}{l}\text { Kent ekosistemine uygun, } \\
\text { endemik türlerin ve/veya } \\
\text { doğal olarak yetişen bitki } \\
\text { ve meyve türlerinin kentsel } \\
\text { alanların } \\
\text { yeşillendirilmesinde } \\
\text { kullanılması }\end{array}$ & $\begin{array}{l}\text { Osmaneli toprak örtüsü bitkisel } \\
\text { olarak çeşitli türlerin } \\
\text { yetişmesine uygundur. Kent } \\
\text { içinde ve çevresinde farklı } \\
\text { meyve ve bitki türleri } \\
\text { yetiştirilmektedir. }\end{array}$ & $\begin{array}{l}\text { Sosyal yeşil alanlar genel } \\
\text { olarak yeşil dokuyu } \\
\text { tamamlayan bitkilerle } \\
\text { çeşitlendirilmiştir. Yeşil } \\
\text { alanlara yönelik tasarım } \\
\text { önerileri Şekil } 5.25 \text { ve Şekil } \\
\text { 5.26'da verilmiştir. }\end{array}$ \\
\hline Kentsel yaşanabilirliğin arttırılması & $\begin{array}{l}\text { Kentin daha yaşanabilir } \\
\text { olması için çalışmalar } \\
\text { yapmak. Örnek olarak işe } \\
\text { gidiş ve çıkış saatlerinde } \\
\text { oluşan trafik sıkışılığını } \\
\text { azaltmak için okulların } \\
\text { veya kamu kurumlarının } \\
\text { mesai saatlerini kaydırmak. } \\
\text { İş yerlerinde kreş } \\
\text { açılmasını teşvik etmek vb. } \\
\text { (Anonim 2020a) }\end{array}$ & $\begin{array}{l}\text { Osmaneli Yavaş Kent ruhuna } \\
\text { uygun bir kenttir. Kent sosyal } \\
\text { ve fiziksel olarak yaşamın } \\
\text { kolay olduğu bir kenttir. }\end{array}$ & $\begin{array}{l}\text { Kentte toplu taşıma } \\
\text { sistemlerinin geliştirilmesi, } \\
\text { sosyal etkinliklerin artırılması } \\
\text { yaşam kalitesini artıracaktır. }\end{array}$ \\
\hline
\end{tabular}


Tablo 1. (Devam Ediyor)

\begin{tabular}{|c|c|c|c|}
\hline $\begin{array}{l}\text { Marjinal alanların tekrar } \\
\text { değerlendirilip kullanılması }\end{array}$ & $\begin{array}{l}\text { Kentte atıl durumda } \\
\text { bulunan alanların } \\
\text { düzenlenmesi, yenilenmesi } \\
\text { kent hayatında işlevsel bir } \\
\text { duruma getirilmesi }\end{array}$ & $\begin{array}{l}\text { Osmaneli için bu tip alan } \\
\text { varlığı ile ilgili net bir bilgi } \\
\text { bulunmamaktadır. }\end{array}$ & $\begin{array}{l}\text { Osmaneli Aya Yorgi Kilisesi } \\
\text { (Şekil 4.6) marjinal sınıf içinde } \\
\text { bir alan olmamakla birlikte } \\
\text { yıkılma tehlikesi nedeniyle } \\
\text { ziyarete açık değildir. Bu alanın } \\
\text { orjinaline uygun bir restorasyon } \\
\text { geçirerek ziyarete açılması } \\
\text { önemli bir kazanım olacaktır. }\end{array}$ \\
\hline $\begin{array}{l}\text { Kirleticilerin izlenmesi ve } \\
\text { azaltılması }\end{array}$ & $\begin{array}{l}\text { Gürültü, elektrik gibi } \\
\text { kirlilik yaratan sistemlerin } \\
\text { izlenmesi ve azaltılmasına } \\
\text { yönelik önlemleri } \\
\text { kapsamaktadır. }\end{array}$ & $\begin{array}{l}\text { Kentte bu anlamda büyük bir } \\
\text { problem göze çarpmamaktadır. }\end{array}$ & $\begin{array}{l}\text { Üniversite ve BEBKA } \\
\text { işbirliğiyle çevresel projeler } \\
\text { üretilerek denetimler } \\
\text { sağlanabilir. }\end{array}$ \\
\hline Sosyal altyapıyı desteklemek & $\begin{array}{l}\text { Kentte sosyal hayatı } \\
\text { geliştirecek uygulamaların } \\
\text { artırılması }\end{array}$ & $\begin{array}{l}\text { Kentte yıllık olarak 'Karpuz } \\
\text { Festivali' yapılmaktadır fakat } \\
\text { yeterli düzeyde değildir. }\end{array}$ & $\begin{array}{l}\text { Ayrıca sanatsal ve sosyal } \\
\text { girişimlerin (konserler, sinema } \\
\text { günleri vb.) kentin sosyal } \\
\text { hayatına olumlu katkıları } \\
\text { olacaktır. }\end{array}$ \\
\hline $\begin{array}{l}\text { Kamusal sürdürülebilir kentsel } \\
\text { planlamanın teşviki }\end{array}$ & $\begin{array}{l}\text { Kent planlamada } \\
\text { sürdürülebilir } \\
\text { yaklaşımların izlenmesi. } \\
\text { Pasif ev, akıllı ev gibi } \\
\text { teknolojilerin } \\
\text { kullanılmasının } \\
\text { özendirilmesi }\end{array}$ & $\begin{array}{l}\text { Kentte bu konuda bir çalışma } \\
\text { yapılmamaktadır. }\end{array}$ & $\begin{array}{l}\text { Kentte sürdürülebilir çalışmalar } \\
\text { konut bazında } \\
\text { bulunmamaktadır. } \\
\text { Sürdürülebilir bir kent için } \\
\text { öncelikle kamu binalarında } \\
\text { sürdürülebilir enerjinin } \\
\text { kullanımı, bisiklet yollarının } \\
\text { artırılması ve motorlu taşıt } \\
\text { kullanımının azaltılmasının } \\
\text { teşvik edilmesi gibi } \\
\text { uygulamalar yapılmalıdır. }\end{array}$ \\
\hline $\begin{array}{l}\text { Kent içindeki kullanışlı yeşil } \\
\text { alanların verimli bitkiler ile } \\
\text { değerlendirilmesi }\end{array}$ & $\begin{array}{l}\text { Kentteki yeşil alanlara } \\
\text { yörede yetişen bitki türleri } \\
\text { ve/veya meyve ağaçları } \\
\text { dikilmesi }\end{array}$ & $\begin{array}{l}\text { Osmaneli oldukça verimli } \\
\text { toprakları bulunan, birçok } \\
\text { meyve ve sebze yetişen bir } \\
\text { bölgedir. Kentsel yeşil } \\
\text { alanlarda meyve ağaçları dikim } \\
\text { uygulaması bulunmamaktadır. }\end{array}$ & $\begin{array}{l}\text { Kentte bulunan birçok park ve } \\
\text { yeşil alanda özellikle meyve } \\
\text { ağaçları dikimi yapılması, bu } \\
\text { dikimler sonucunda elde edilen } \\
\text { ürünlerin bir kooperatif altında } \\
\text { reçel vb. yapılıp satılarak } \\
\text { değerlendirilmesi kente girdi } \\
\text { olarak dönecektir. }\end{array}$ \\
\hline $\begin{array}{l}\text { Atölyelerin korunması ve } \\
\text { değerlerinin arttırılması-doğal/yerel } \\
\text { alışveriş merkezlerinin yaratılması }\end{array}$ & $\begin{array}{l}\text { Tarihi kent merkezlerinde } \\
\text { yer alan geleneksel kasap, } \\
\text { firın, bakkal vb. } \\
\text { dükkanların desteklenmesi } \\
\text { (Anonim 2020a) }\end{array}$ & $\begin{array}{l}\text { Kentte yetişen ayva lokumu, } \\
\text { lefke bezi yerel ürünlerin } \\
\text { satıldığı az sayıda dükkan } \\
\text { bulunmaktadır. }\end{array}$ & $\begin{array}{l}\text { Kentteki yerel ürünlerin ve } \\
\text { kırsal kadınların ürettiği } \\
\text { ürünlerin satılması hem kent } \\
\text { ekonomisini güçlendirecek, } \\
\text { hem de kentteki ürünlerin } \\
\text { tanınırlığını artıracaktır. }\end{array}$ \\
\hline $\begin{array}{l}\text { Yeşil alanlarda kullanılan beton } \\
\text { miktarı }\end{array}$ & $\begin{array}{l}\text { Yeşil alanlarda kullanılan } \\
\text { beton miktarlarının } \mathrm{m}^{3} \\
\text { olarak tespit edilmesi }\end{array}$ & $\begin{array}{l}\text { Osmaneli'de oldukça fazla } \\
\text { yeşil alan bulunmaktadır. } \\
\text { Buralarda kullanılan beton } \\
\text { miktarına ilişkin bir çalışma } \\
\text { bulunmamaktadır. }\end{array}$ & $\begin{array}{l}\text { Osmaneli'de geniş yeşil alanlar } \\
\text { bulunmaktadır. Buralarda } \\
\text { kullanılan beton miktarlarını } \\
\text { saptamak uzaktan algılama } \\
\text { sistemleriyle ya da doğrudan } \\
\text { arazi çalışmalarıyla yapılabilir. }\end{array}$ \\
\hline $\begin{array}{l}\text { El yapımı ve etiketli veya markalı } \\
\text { esnaf/sanatkâr ürünlerinin } \\
\text { korunması }\end{array}$ & $\begin{array}{l}\text { Kentte üretilen yerel } \\
\text { ürünlerin desteklenmesi }\end{array}$ & $\begin{array}{l}\text { Kentte bu kapsamda yerel } \\
\text { ürünlerin üretimini artırmak } \\
\text { için (özellikle lefke bezinin } \\
\text { üretimi) kadın girişimcilere } \\
\text { yönelik kurslar } \\
\text { düzenlenmektedir. }\end{array}$ & $\begin{array}{l}\text { Kentte kooperatifleşme yoluyla } \\
\text { yerel ürünlerin markalaşması } \\
\text { desteklenebilir. }\end{array}$ \\
\hline $\begin{array}{l}\text { Yerel ve geleneksel kültürel } \\
\text { etkinliklerin korunması ve } \\
\text { değerlerinin arttırılması }\end{array}$ & $\begin{array}{l}\text { Kentteki yerel ve } \\
\text { geleneksel etkinliklerin } \\
\text { korunmasına yönelik } \\
\text { çalışmaları kapsamaktadır. }\end{array}$ & $\begin{array}{l}\text { Osmaneli katmanlı bir Türk, } \\
\text { Osmanlı ve mübadele yoluyla } \\
\text { gelen Rum kültürünü bir arada } \\
\text { yaşatmaktadır. }\end{array}$ & $\begin{array}{l}\text { Yöresel etkinlikler ve yemekler } \\
\text { çeşitli festivallerle } \\
\text { desteklenerek yaşatılabilir. }\end{array}$ \\
\hline
\end{tabular}




\begin{tabular}{|c|c|c|}
\hline & $\begin{array}{l}\text { BŞEÜ Fen Bilimleri Dergisi } \\
8(1), 369-382,2021\end{array}$ & $\begin{array}{r}\text { BSEU Journal of Science } \\
\text { https://doi.org/10.35193/bseufbd.925822 }\end{array}$ \\
\hline $\begin{array}{l}\text { BïLECIK SEYH EDEBALI| } \\
\text { UNIVERSITES I }\end{array}$ & & 2458-7575 (https://dergipark.org.tr/tr/pub/bseufbd) \\
\hline
\end{tabular}

Tablo 1. (Devam Ediyor)

\begin{tabular}{|l|l|l|l|}
\hline $\begin{array}{l}\text { Yavaş güzergahların mevcut } \\
\text { olması }\end{array}$ & $\begin{array}{l}\text { Kentte Yavaş seyahat } \\
\text { rotaları oluşturmak ve } \\
\text { bunları basılı olarak ve } \\
\text { internet ortamında } \\
\text { tanıtmak }\end{array}$ & $\begin{array}{l}\text { Osmaneli halihazırda Yavaş } \\
\text { Kent olmadığı için bir yavaş } \\
\text { güzergahı bulunmamaktadır. }\end{array}$ & $\begin{array}{l}\text { Kent için bir gezi rotası önerisi } \\
\text { proje kapsamında geliştirilmiş } \\
\text { ve Şekil 5.27'de } \\
\text { gösterilmektedir. }\end{array}$ \\
\hline $\begin{array}{l}\text { Gençlik faaliyetlerinin yürütüldüğü } \\
\text { alanların ve bir gençlik merkezinin } \\
\text { mevcudiyeti }\end{array}$ & $\begin{array}{l}\text { Gençlere özgü alanların } \\
\text { bulunması ve etkinliklerin } \\
\text { yapılması }\end{array}$ & $\begin{array}{l}\text { Bu kapsamda özel alanlar } \\
\text { bulunmamaktadır. }\end{array}$ & $\begin{array}{l}\text { Kentte bu tip alanlar } \\
\text { yaratıllması gençlerin kentte } \\
\text { daha keyifli, kaliteli zaman } \\
\text { geçirmesini sağlayacak, ayrıca } \\
\text { kent hayatına katıllımı } \\
\text { artıracaktır. }\end{array}$ \\
\hline
\end{tabular}

Yukarıda yapılan saptamalar doğrultusunda kent imajını güçlendirecek bazı temel konulara ilişkin, Osmaneli'de çekilen fotoğraflarda yapılan görselleştirme çalışmaları ile çözüm önerileri getirilmiştir. Öncelikle kent peyzajına yönelik bazı konu başıkları belirlenerek bu başlıklar altında kent imajını geliştirmeye yönelik görselleştirme çalışmaları yapılmıştır.

Kent peyzajına yönelik üzerinde durulan konu başlıkları şu şekildedir:
a. Kent Estetiği
b. Meydanlar
c. Sokaklar
d. Yapı cepheleri
e. Yeşil alanlar

\section{A. Kent Estetiği}

Kent estetiğinin artıılması, kent imajını güçlendirmenin en önemli belirleyicisidir. Kent dokusunda yaşanacak olumlu değişimler kentin, insanların anı ve hafizalarındaki yerini güçlendirecek ve Osmaneli'ye ilişkin olumlu bakış açısını destekleyecektir. Bu bağlamda kent estetiğini güçlendirmek adına iki fotoğraf üzerinde çalışma yapılmıştır. Şekil 2'de görülen ilk fotoğrafta Osmaneli'nin merkezi bir bölgesinde bulunan sokakta birbiriyle bütünleşmeyen estetikten uzak yapılar ve donatı elemanları bulunmaktadır. Görselleştirme çalışması kapsamında yapılara estetik bir görünüm kazandırılmış, aydınlatma elemanı olarak; sürdürülebilirliğin önemli ilkelerinden olan yenilenebilir enerji kullanımının aktifleşmesini sağlamak üzere solar panelli aydınlatmalar ve geri dönüşümlü çöp kutuları tercih edilmiştir. Ayrıca yapıların önüne park eden araçlar kaldırılarak, bitkilendirme artırılmıştır.

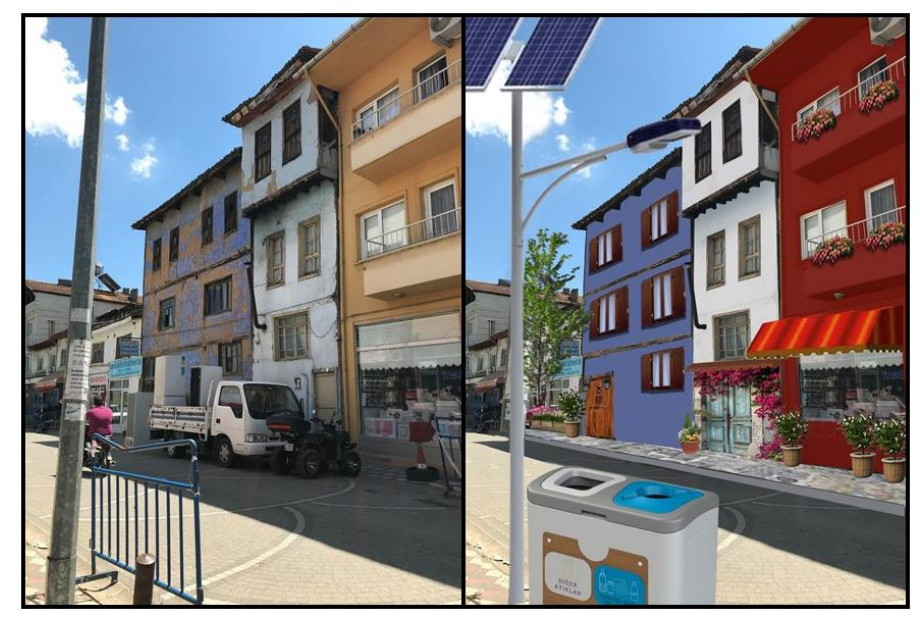

Şekil 2. Kent estetiğine ilişkin birinci görselleştirme çalışması

Kent estetiği konusunda üzerinde çalışılan Şekil 3'deki ikinci fotoğrafta kent mobilyası olarak önemli bir öge olan otobüs durakları üzerine çalışılmıştı. Osmaneli'deki durağın tanımsız ve kimliksiz durumunun değişmesi için Dünya kentlerindeki farklı durak tiplerinden yola çıkılarak bir otobüs durağı çalışması yürütülmüştür. 


\begin{tabular}{|c|c|c|}
\hline & $\begin{array}{l}\text { BŞEÜ Fen Bilimleri Dergisi } \\
8(1), 369-382,2021\end{array}$ & $\begin{array}{r}\text { BSEU Journal of Science } \\
\text { https://doi.org/10.35193/bseufbd.925822 }\end{array}$ \\
\hline 0 & & 2458-7575 (https://dergipark.org.tr/tr/pub/bseufbd) \\
\hline
\end{tabular}

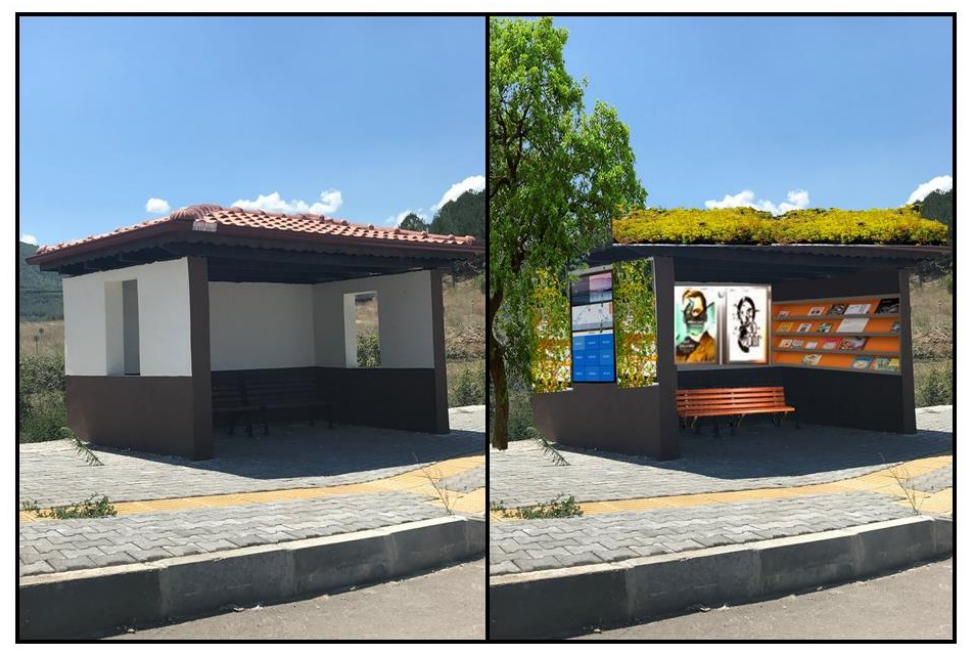

Şekil 3. Kent estetiğine ilişkin ikinci görselleştirme çalışması

\section{B. Meydanlar}

Kentte imaj ve kimliği tamamlayıcı önemli ögelerden bir başkası, insanların toplanma noktası olan, kentlerdeki önemli etkinliklerin yapıldığı, dışarıdan gelen insanların ilk gördükleri alanlardır. Şekil 4'de görüldüğü üzere Osmaneli merkezdeki meydan genel olarak estetik açıdan tanımlı bir meydan olmakla birlikte küçük bazı düzenlemelerle daha etkili hale getirilmiştir.

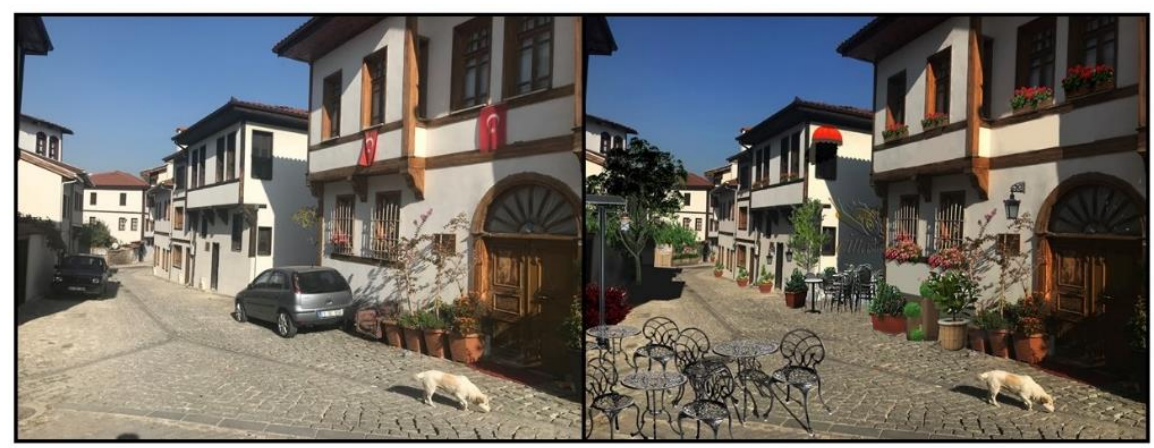

Şekil 4. Osmaneli kent meydanına ilişkin birinci görselleştirme çalışması

Osmaneli oldukça küçük bir yerleşim olduğundan meydan vasfı taşıyan çok fazla alan bulunmamaktadır. İnsanların rekreatif amaçlarla kullandığı Şekil 5'de görülen ikinci alan bu kapsamda değerlendirilmiştir. Yeşil dokunun artırılması, oturma alanlarının estetik ve doğal malzemeyle zenginleştirilmesi ve döşeme elemanlarının güzelleştirilmesi fikri esas alınarak görselleştirme çalışması gerçekleştirilmiştir.

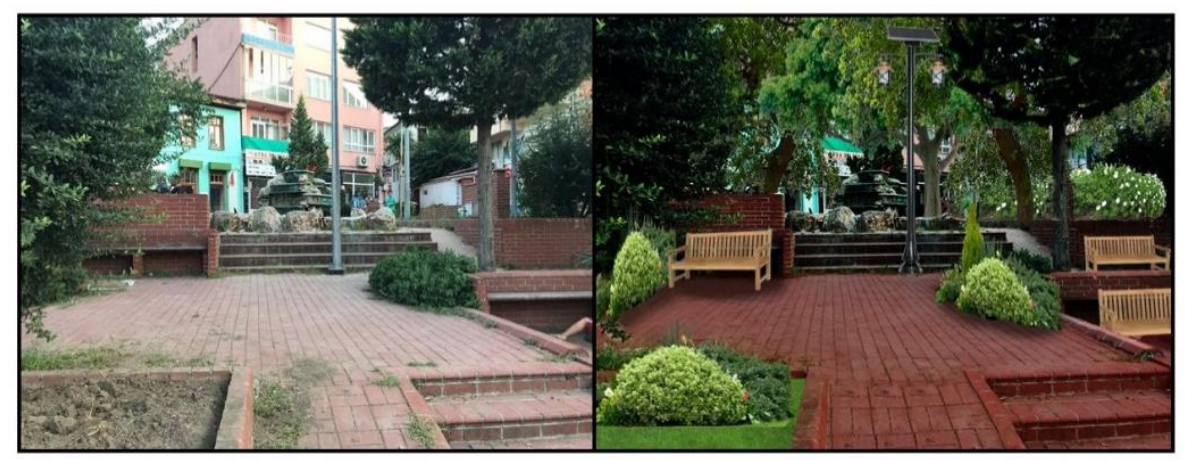

Şekil 5. Osmaneli kent meydanına ilişkin ikinci görselleştirme çalışması 


\begin{tabular}{|c|c|c|}
\hline & $\begin{array}{l}\text { BŞEÜ Fen Bilimleri Dergisi } \\
8(1), 369-382,2021\end{array}$ & $\begin{array}{r}\text { BSEU Journal of Science } \\
\text { https://doi.org/10.35193/bseufbd.925822 }\end{array}$ \\
\hline 0 & & 2458-7575 (https://dergipark.org.tr/tr/pub/bseufbd) \\
\hline
\end{tabular}

\section{Sokaklar}

Osmaneli’nin tarihi konut dokusu ve tescilli yapıları sayesinde sokaklar kimlikli bir nitelik taşımaktadır. Şekil 6 ve Şekil 7'de cam önü bitkileri ve saksılar yardımıyla sokaklar yeşillendirilerek daha cazip bir hale getirilmiştir. Ayrıca solar panelli aydınlatmalar sokakların etkili şekilde aydınlatılması ve güvenliğin sağlanması açısından tercih edilmiştir. Yer döşemelerinde değişiklik yapılmamıştır.

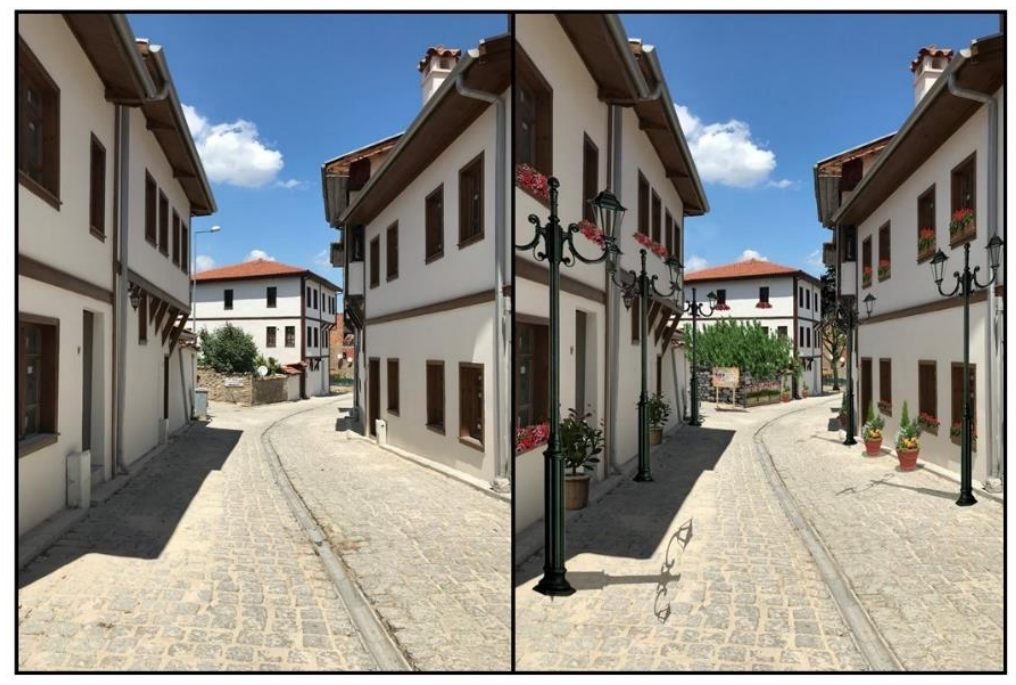

Şekil 6. Osmaneli Sokakları'na ilişkin birinci görselleştirme çalışması

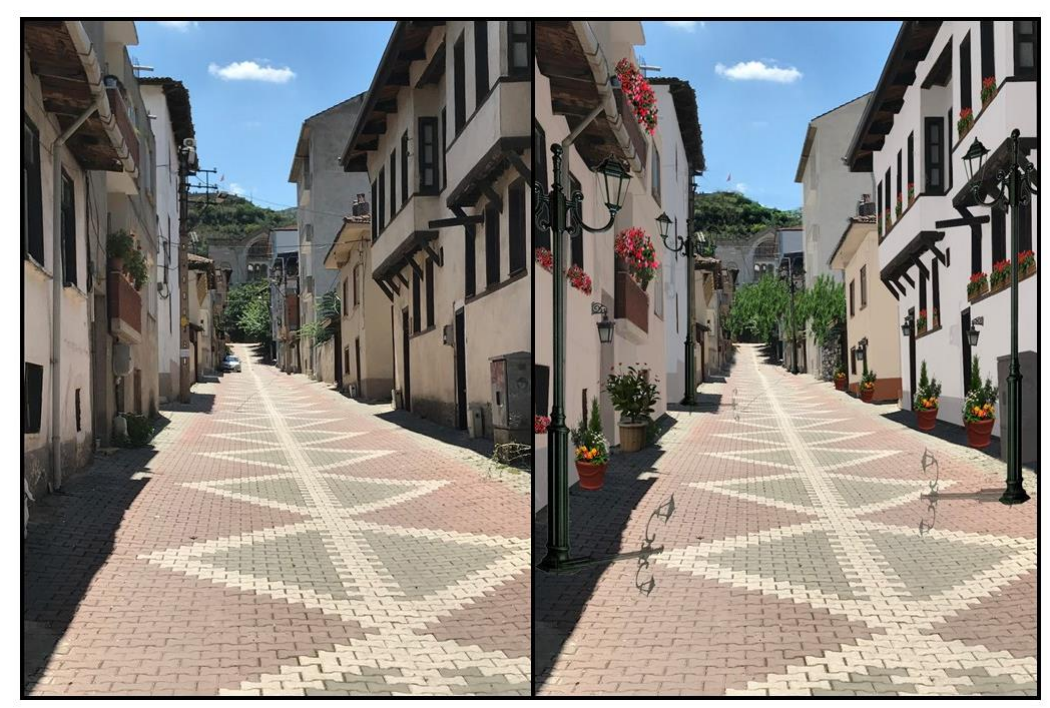

Şekil 7. Osmaneli Sokakları'na ilişkin ikinci görselleştirme çalışması

\section{Yapt Cepheleri}

Yapı cepheleri kent imajını güçlendiren çok önemli ögelerdir. Ayrıca Yavaş Kent Hareketi açısından yapı cephelerinin iyileştirilmesi önemli bir kavram olarak yer almaktadır. Bu kapsamda Şekil 8'de biraz yıpranmış olan yapı cephesi iyileştirilmiş ve bitkisel ögelerle zenginleştirilmiştir. 


\begin{tabular}{|c|c|c|}
\hline & $\begin{array}{l}\text { BŞEÜ Fen Bilimleri Dergisi } \\
8(1), 369-382,2021\end{array}$ & $\begin{array}{r}\text { BSEU Journal of Science } \\
\text { https://doi.org/10.35193/bseufbd.925822 }\end{array}$ \\
\hline $\begin{array}{l}\text { BILECIK SEYY EDEBALI } \\
\text { UN IVERSITESI }\end{array}$ & & 2458-7575 (https://dergipark.org.tr/tr/pub/bseufbd) \\
\hline
\end{tabular}

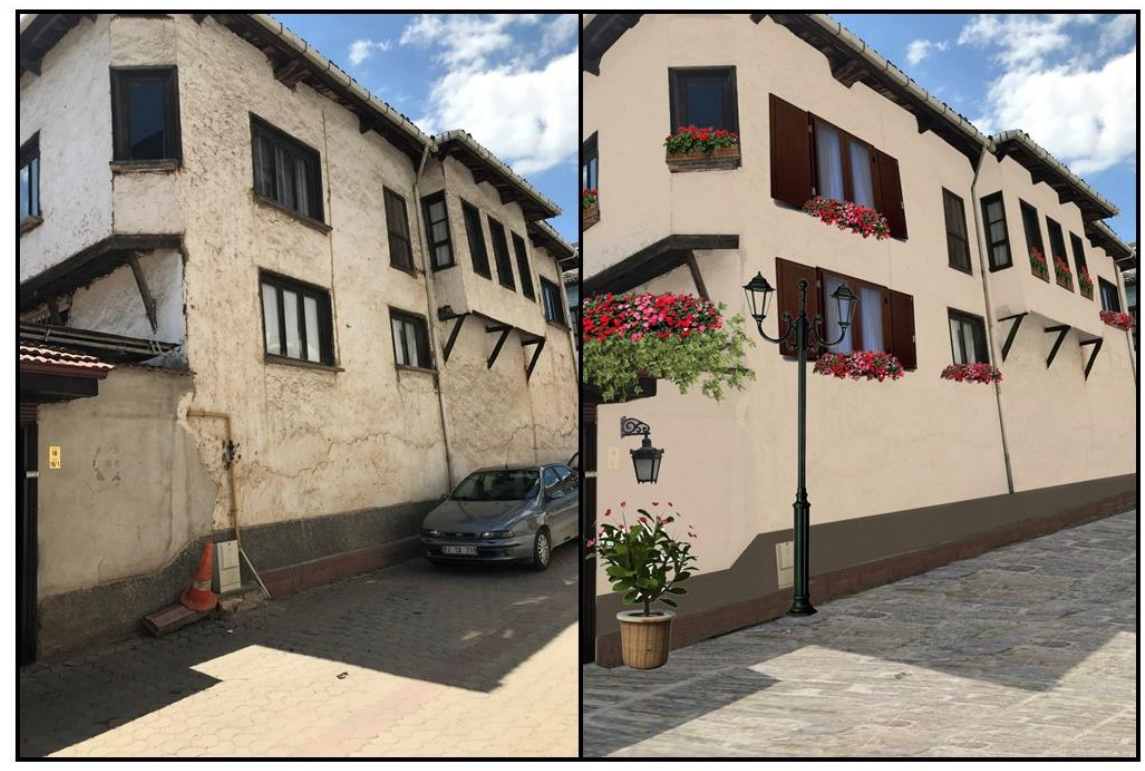

Şekil 8. Osmaneli’ndeki yapı cephelerine ilişkin birinci görselleştirme çalışması

Osmaneli'de yapılan yapı cephesine ilişkin ikinci çalışma olan Şekil 9'da Osmaneli tarihi konutlarının bazılarının geçmişte çivit mavisi olduğu bilgisinden yola çıkılarak mavi renk tercih edilmiştir. Dükkan levhaları ve tabelalarda ahşap estetik kullanımlar ve tenteli gölgelendirme elemanları kullanılmıştır. Dükkan önü oturma birimleri kimlikli Avrupa kentlerinde özellikle kullanılan, kentsel dış mekanda geçirilen zamanı keyifli kılan kent mobilyaları olarak tercih edilmiştir.

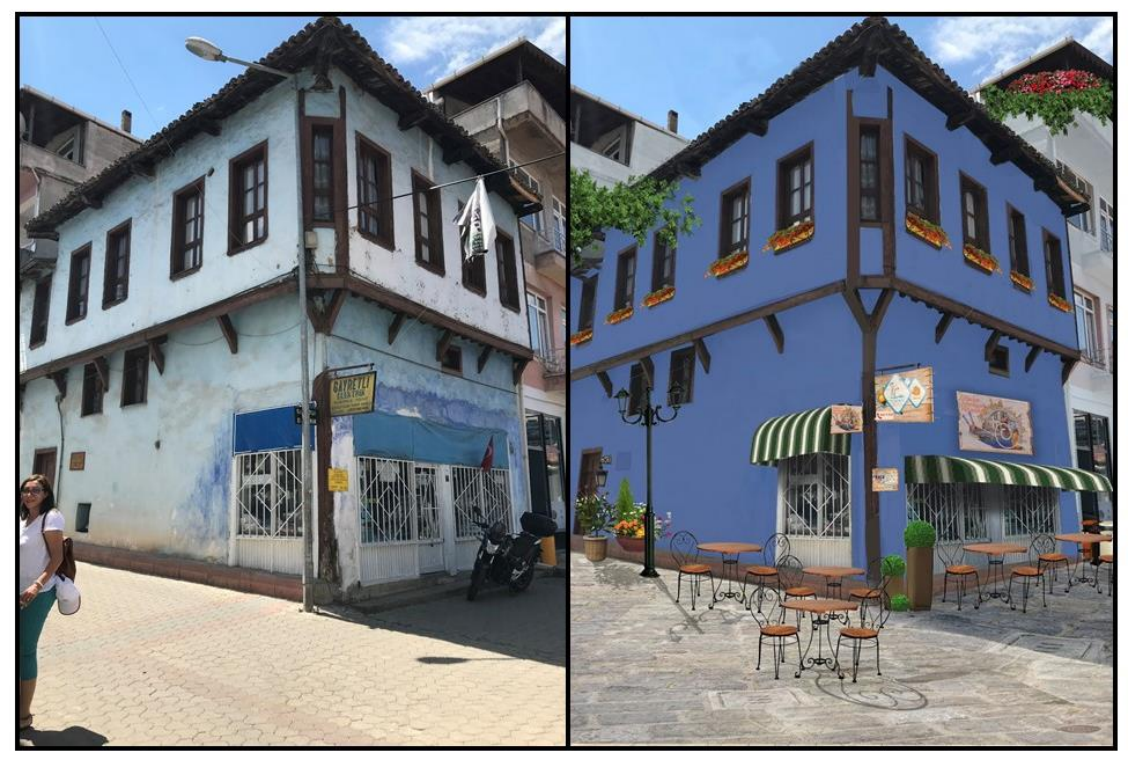

Şekil 9. Osmaneli’ndeki yapı cephelerine ilişkin ikinci görselleştirme çalışması

\section{E. Yeşil Alanlar}

Kent peyzajının önemli değerleri olan yeşil alanlar, aynı zamanda nitelikli kentsel alanlarda insanların rekreatif etkinliklerde bulundukları sosyal ve fiziksel olarak önemli imaj ögeleridir. Yeşil alanların insan psikolojine olumlu etkilerini ortaya koyan çalışmalar her geçen gün artmaktadır. Dolayısıyla yeşil alanların varlığı ve tasarımı önem kazanmaktadır. Osmaneli'de özellikle Sakarya Nehri kıyısında insanların etkin olarak kullandıkları yeşil alanlar bulunmaktadır. Şekil 10'da bulunan yeşil alan kentsel dokuyu güçlendirecek bitkiler ve ağaçlarla desteklenmiş ve yer döşemesi değiştirilmiştir. 


\begin{tabular}{|c|c|c|}
\hline & $\begin{array}{l}\text { BŞEÜ Fen Bilimleri Dergisi } \\
8(1), 369-382,2021\end{array}$ & $\begin{array}{r}\text { BSEU Journal of Science } \\
\text { https://doi.org/10.35193/bseufbd.925822 }\end{array}$ \\
\hline $\begin{array}{l}\text { BILECIK SEYY EDEBALI } \\
\text { UN IVERSITESI }\end{array}$ & & 2458-7575 (https://dergipark.org.tr/tr/pub/bseufbd) \\
\hline
\end{tabular}

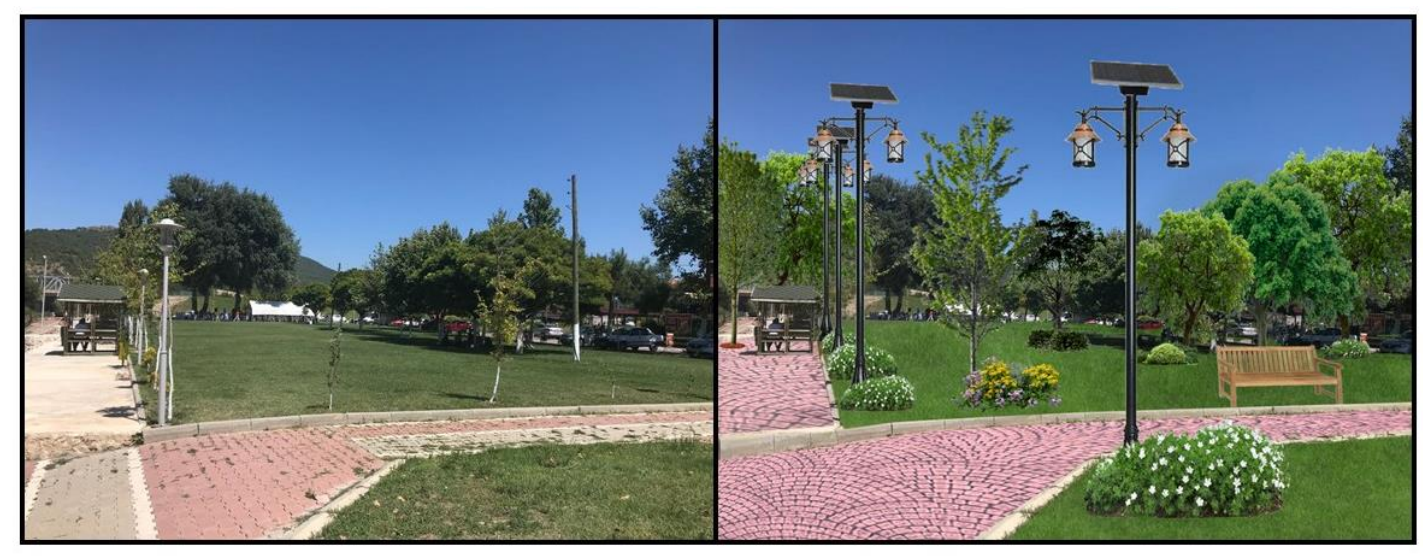

Şekil 10. Osmaneli'ndeki yeşil alanlara ilişkin birinci görselleştirme çalışması

Şekil 11'deki ilk fotoğrafta Osmaneli'nin üst kısmında katlı konutların bulunduğu, kısmen atıl vaziyetteki bir alan görülmektedir. Bu bölge nitelikli bir yeşil alana dönüşme potansiyeli düşünülerek yeniden tasarlanmış, bitkisel ve yapısal ögelerle desteklenmiştir.

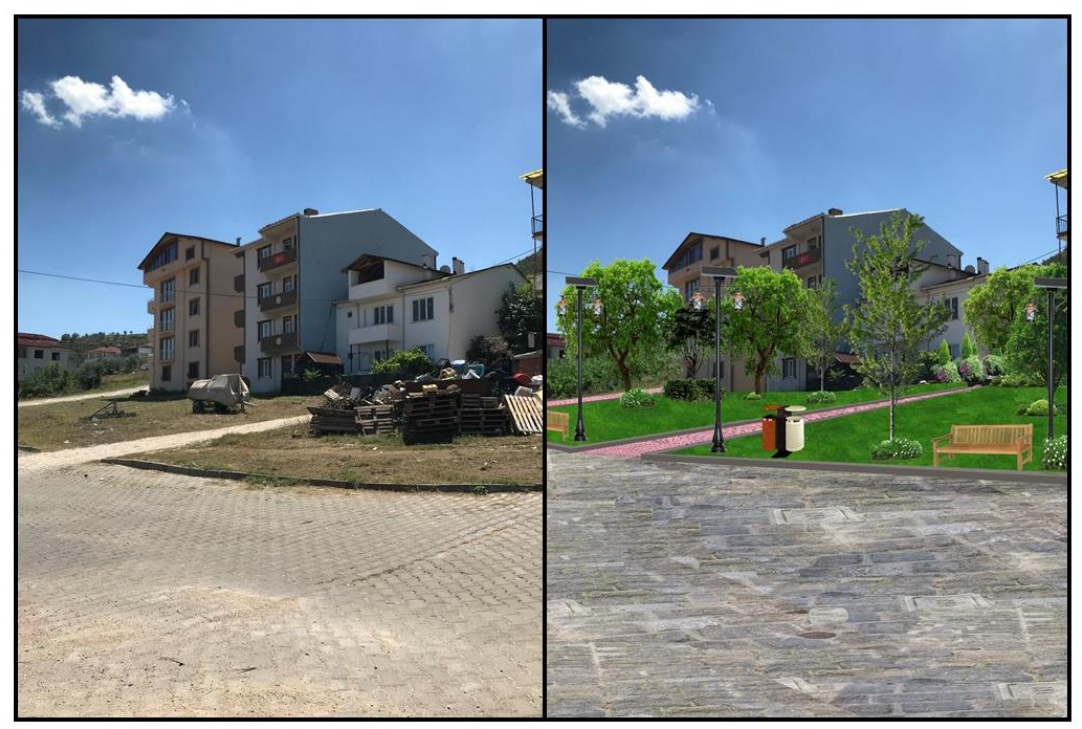

Şekil 11. Osmaneli’ndeki yeşil alanlara ilişkin ikinci görselleştirme çalışması

\section{SONUÇ VE ÖNERILER}

Küreselleşme; kapitalizm ve bileşenlerinin ortaya çıkardığı, tüketim odaklı sistemlerin bir ürünüdür. Bilginin ve ürünlerin tüm Dünya'da hızlı bir şekilde dağılımı küreselleşmenin olumlu bir yanı olarak görülürken, tüketime dayalı yaşam biçiminin dayatmaları kentlerde özgün dokunun kaybolmasına sebep olmaktadır. $\mathrm{Bu}$ sistemden mimari, yeme biçimleri ve kültürel üretim ve etkinlikler olumsuz olarak etkilenmektedir. Özellikle büyük kentlerde değişim çok daha büyük ölçüde hissedilmekle birlikte, küçük ölçekli yerleşimlerde coğrafi konum, denize kıyısı olması, rant değeri gibi belirleyicilerle farklı boyutlarda etkileşim göstermektedir.

Bilecik Türkiye'nin en küçük ölçekli ve nüfuslu illerinden biridir. Tarihi ve kültürel dokusunu koruma konusunda kent merkezi ve çeperdeki yerleşimler açısından dirençli bir yapı sergilemektedir. Osmaneli Bilecik'in ilçelerinden biri olarak, oldukça korunaklı bir tarihi silüete sahip, çok çeşitli tarım ürünleri ve yöresel lezzetleri bulunan markalaşma değeri yüksek bir yerleşimdir. Geçmişte çeşitli uygarlıklara ev sahipliği yapması, ipek böcekçiliği ve kozacılık faaliyetlerinin burada sürdürülmüş olması, Osmanlı Devleti'nin Bilecik ve çevresinde hüküm sürmesi ve mübadele döneminde yerleșen Rum halkın da etkisiyle mimari ve kültürel bir mozaik sergilemektedir. 
Çalışma kapsamında; Bilecik İli Osmaneli yerleşiminin Yavaş Kent Hareketi'ne katılım potansiyelinin kentin imaj değeri üzerinden irdelenmesi amacıyla 2019-2020 yılları arasında, farklı zaman dilimlerinde araştırma alanı ile ilgili gözlemler yapılmış, fotoğraflar çekilmiş ve anket uygulamaları yapılmıştır. Çeşitli kurum ve kuruluşların yayınlarından faydalanılarak, yerel yönetim, yerel halk ve ziyaretçilerle yüz yüze görüşmeler yapılarak görsel kaynak, yazı, rapor gibi Osmaneli'ye ilişkin veriler elde edilmiştir. Elde edilen bulgular sistematik bir sınıflandırmaya tabi tutularak düzenli bir veri tabanı oluşturulmuştur. Çalışma konusunda birincil kısıtlayıcı etmen yerel halkın bir kısmının anket uygulamalarına katılma konusunda isteksizlik duyması olmuştur. Ayrıca proje süreci içerisinde Covid-19 pandemisinin başlamış olması da anket ve fotoğraflama konusunda elde edilen birincil verilerle yetinilmesini zorunlu kılmıştır.

Daha önceki bölümlerde bahsedildiği üzere; Yavaş Kent Hareketi'ne katılmak isteyen bir kentin belirli koşulları sağlamak, diğerlerini de sağlayacağını taahhüt etmesi gerekmektedir. Osmaneli yerleşimi bu bağlamda şanslı bir pozisyondadır. Bilecik'e bağlı küçük bir yerleşim olması sebebiyle kentsel müdahalelerden çok fazla etkilenmemiş ve özgün dokusunu korumuştur. Bununla birlikte, Osmaneli'nin kent imajını güçlendirmek ve turizm potansiyelini artırmak kente ekonomik kalkınma sağlayacaktır. Bu bağlamda Osmaneli'nin imajını vurgulamak ve Yavaş Kent olmasını sağlamak üzere aşağıdaki öneriler sunulmuştur:

- Belediyenin ve tüm yerel yönetimlerin Yavaş Kent ağına katılma konusunda detaylı olarak bilgilendirilmesi ve Bilecik Şeyh Edebali Üniversitesi işbirliğiyle bu sürecin yönlendirilmesi

- Yerel halka yönelik bilgilendirme toplantıları ve çalıştaylar düzenlenmesi

- Kentteki eksikliklerin belirlenmesi ve giderilmesine yönelik çalışmaların yürütülmesi

- Tescillenmiş ve tescile önerilen tarihi konut ve yapılara ilişkin bilgileri içeren afiş, döküman vb. envanterlerin çıkarılması

- Kentin imajını güçlendirmeye yönelik tüm özelliklerin bir arada değerlendirilerek turizm envanterlerinin çıkarılması

- Kente gelenlere kenti tanıtmaya yönelik bir seyahat rotası oluşturulması ve bunun için gerekli dökümanların hazırlanması

- Doğa turizmini vurgulayacak tanıtım broşürleri hazırlanması ve turizm rotaları oluşturulması

- Osmaneli'ye yönelik bisiklet rotası oluşturulması

- Yerel ve ulusal basınla entegre bir biçimde tanıtım video ve görsellerinin medyaya servis edilmesi

- Kentin tüm noktalarında kiosklar oluşturarak tüm bu tanıtıcı envanterlerin dijital ortamda ve basılı olarak insanlara ulaştırılması

\section{TEŞEKKÜR}

Yazarlar, 2018-02.BŞEÜ.07-02 no'lu proje kapsamında, Bilecik Şeyh Edebali Üniversitesi Bilimsel Araştırma Projeleri Koordinatörlüğüne verdiği destek için teşekkür eder.

\section{KAYNAKLAR}

[1] Perihan, M. \& Aşur, F. (2020). Tarihi Kentsel Peyzaj ve Kent Kimliği İlişkisi. Kent Akademisi: Kent Kültürü ve Yönetimi Dergisi, 13(1), 163-175.

[2] Scheffler, N., Kulikauskas, P. \& Barreiro, F. (2009). Managing Urban Identities: Aim or Tool of Urban Regeneration?. The Urbact Tribune, 9-13.

[3] Aly, S. S. A. (2011). Modernization and Regionalism: Approaches for Sustainable Revival of Local Urban Identity. International Conference on Green Buildings and Sustainable Cities, Science Direct Procedia Engineering, 21, 503-512.

[4] Yargıç, S. (2009). Küreselleşen Kentlerde İkonik Yapıların Kentsel Kimlik Oluşumuna Etkileri Üzerine İrdeleme. Yıldız Teknik Üniversitesi, Fen Bilimleri Enstitüsü, Mimarlık Anabilim Dalı, Yüksek Lisans Tezi. İstanbul.

[5] Larco, N. (2010). Both/And: Merging Global and Local Identity through Design. A Case Study of Puerto Madero, Buenos Aires. Journal of Urban Design, 15 (2), 195-210.

[6] Dağ, V. \& Mansuroğlu, S. (2020). Turizm Alanlarının Kent Kimliğine Etkisi: Denizli Kenti Örneği. Atatürk Üniversitesi Sosyal Bilimler Enstitüsü Dergisi, 24 (2), 589-604.

[7] Fırat, A. \& Kömürcüoğlu, F. (2015). Muğla Şehir Markası ve İmaj Algısı; Muğla Sttkı Koçman Üniversitesi Öğrencileri Üzerine Bir Alan Araştırması. Yönetim Bilimleri Dergisi, 13(26), 285-304.

[8] Oğurlu, İ. (2014). Çevre-Kent İmaj1-Kent Kimliği-Kent Kültürü Etkileşimlerine Bir Bakış. İstanbul Ticaret Üniversitesi Fen Bilimleri Dergisi, 13(26), 275-293. 
[9] Lynch, K. (2010). Kent İmgesi, Türkiye İş Bankası Kültür Yayınları, 215.

[10] Elovich, M. A. (2012). Becoming Cittaslow a City's Journey to Becoming a Cittaslow Member. Faculty of California Polytechnic State University, In Partial Fulfillment of the Requirements for the Degree Master of City and Regional Planning.

[11] Knox, P. L. (2005). Creating Ordinary Places: Slow Cities in a Fast World, Journal of Urban Design, 10(1), $1-11$.

[12] Güven, E. (2011). Yavaş Güzeldir: 'Yavaş Yemek’ten 'Yavaş Medya’ya Hızlı Tüketime Dair Bir Çözüm Önerisi. Selçuk Illetişim, 7(1), 113-121.

[13] Gündüz, C. (2012). Pragmatism and Utopia Under the Auspices of Neoliberalism: Turning Out to be Cittaslow of Seferihisar. Orta Doğu Teknik Üniversitesi Sosyoloji Bölümü Doktora Tezi, Ankara.

[14] Pink, S. (2009). Urban social movements and small places: Slow Cities as sites of activism. City: analysis of urban trends, culture, theory, policy, action, 13(4), 451-465.

[15] Ersavaş Kavanoz, S. \& Budak, S. (2020). Yavaş Kent'in Otantiklik/ Özgünlük Bağlaminda Kent Pazarlama Stratejisi Olarak Okunması. Hacettepe Üniversitesi İktisadi ve İdari Bilimler Fakültesi Dergisi, 38 (3), 487 509.

[16] Soyocak Özalp, S. (2020). Küresele karşı yerel: Yavaş kent yaklaşımı. Journal of Social and Humanities Sciences Research, 7(61), 3297-3303.

[17] Miele, M. (2008). CittàSlow: Producing Slowness against the Fast Life, Space and Polity. 12(1), $135-156$.

[18] Anonim. 2020. Web Sitesi: www.cittaslowturkiye.org, (Erişim Tarihi: 10.01.2020)

[19] Kayaoğlu, B. \& Yazar, A. (2021). Sakin Kent (Cittaslow) ve Ekoturizmin Birlikte Uygulanması: Türkiye. Akademik Düşünce Dergisi, 2021(3), 3-18.

[20] Baş, T. (2003). Anket“AAnket Nasıl Hazırlanır? Anket Nasıl Uygulanır? Anket NasılDeğerlendirilir?, Seçkin Yayıncılık, 222,. Ankara. 